\title{
Obesity, Weight Loss, Lifestyle Interventions, and Autosomal Dominant Polycystic Kidney Disease
}

\author{
Cortney Steele (1) and Kristen Nowak* \\ Division of Renal Diseases and Hypertension, Anschutz Medical Campus, University of Colorado, \\ Aurora, CO 80045, USA; cortney.steele@cuanschutz.edu \\ * Correspondence: kristen.nowak@cuanschutz.edu; Tel.: +1-303-724-4842
}

check for

updates

Citation: Steele, C.; Nowak, K.

Obesity, Weight Loss, Lifestyle Interventions, and Autosomal Dominant Polycystic Kidney Disease. Kidney Dial. 2022, 2, 106-122. https://doi.org/10.3390/ kidneydial2010013

Academic Editors: Roman-Ulrich Müller, Sharlene A. Greenwood and Ellen M. Castle

Received: 1 February 2022

Accepted: 24 February 2022

Published: 4 March 2022

Publisher's Note: MDPI stays neutral with regard to jurisdictional claims in published maps and institutional affiliations.

Copyright: () 2022 by the authors. Licensee MDPI, Basel, Switzerland. This article is an open access article distributed under the terms and conditions of the Creative Commons Attribution (CC BY) license (https:// creativecommons.org/licenses/by/ $4.0 /)$.

\begin{abstract}
Obesity remains a growing public health concern in industrialized countries around the world. The prevalence of obesity has also continued to rise in those with chronic kidney disease. Epidemiological data suggests those with overweight and obesity, measured by body mass index, have an increased risk for rapid kidney disease progression. Autosomal dominant polycystic kidney disease causes growth and proliferation of kidney cysts resulting in a reduction in kidney function in the majority of adults. An accumulation of adipose tissue may further exacerbate the metabolic defects that have been associated with ADPKD by affecting various cell signaling pathways. Lifestyle interventions inducing weight loss might help delay disease progression by reducing adipose tissue and systematic inflammation. Further research is needed to determine the mechanistic influence of adipose tissue on disease progression.
\end{abstract}

Keywords: adipose tissue; chronic kidney disease; weight loss

\section{Introduction}

The definition of obesity simplified is excessive body weight relative to height; however, the phenotype draws complex alterations metabolically and has detrimental effects on an individual's overall health [1]. The World Health Organization (WHO), International Obesity Task Force (IOTF), among other reputable organizations, recognize that for those $\geq 20$ years of age, a body mass index (BMI) ranging from 18.50 to $24.99 \mathrm{~kg} / \mathrm{m}^{2}$ is normal, $\geq 25.00$ to $29.99 \mathrm{~kg} / \mathrm{m}^{2}$ is overweight, and $\geq 30.00 \mathrm{~kg} / \mathrm{m}^{2}$ is obese [2].

The prevalence of obesity continues to rise and is a major public health concern in industrialized countries globally [3-5]. Individuals with obesity are at risk for developing comorbid conditions including cardiovascular disease (CVD), hypertension, gastrointestinal disorders, chronic kidney disease (CKD), type 2 diabetes (T2D), as well as other diseases that may indirectly increase mortality risk [6,7].

Obesity indirectly causes strain on the kidneys by increasing blood pressure, intensifying renal tubular sodium reabsorption, and weakening pressure natriuresis [8-10]. These events lead to volume expansion by stimulation of the sympathetic nervous system and the renin-angiotensin-aldosterone system (RAAS) [11-14]. Physical compression of the kidneys from surplus visceral adipose tissue also impacts kidney health and function $[11,15,16]$. Obesity also can lead to renal vasodilation and glomerular hyperfiltration that initially serve as compensatory mechanisms to maintain a sodium balance in the face of increased tubular reabsorption [17]. These potential mechanisms may make obesity a risk for the development and progression of chronic kidney disease (CKD) [11,17-20].

Similar to the general population, evidence suggests obesity is on the rise in those with CKD [21]. The average BMI from 1995 to 2002 has increased from 25.7 to $27.5 \mathrm{~kg} / \mathrm{m}^{2}$ in patients with end-stage kidney disease (ESKD) [22]. The incidence of total obesity and obesity stage 2 (BMI and $>35 \mathrm{~kg} / \mathrm{m}^{2}$ ) increased by 33 and $63 \%$, respectively, in this ESKD cohort [22]. In a large cohort study consisting of 3334 CKD patients from Queensland, 
Australia in 2011, 18.9\% had a normal BMI (18.5-24.9 kg/m²), 29.9\% were overweight (BMI $\left.25-29.9 \mathrm{~kg} / \mathrm{m}^{2}\right), 25.1 \%$ were mildly obese (BMI $30-34.9 \mathrm{~kg} / \mathrm{m}^{2}$ ), and $26.1 \%$ were moderately obese+ $\left(\mathrm{BMI} \geq 35 \mathrm{~kg} / \mathrm{m}^{2}\right)$. Thus, in this cohort, $81.1 \%$ of the CKD patients were either overweight or obese [23].

Polycystic kidney disease (PKD), a form of CKD, is the most common genetic cause of kidney failure affecting $>10$ million people worldwide [24]. The genetic disorder is characterized by progressive development and enlargement of multiple renal cysts that ultimately lead to loss of kidney function in the majority of afflicted patients [25]. Autosomal dominant PKD (ADPKD) is the most common form of PKD and is primarily caused by mutations in the PKD1 and PKD2 genes, encoding the polycystin 1 and polycystin 2 proteins (Figure 1) [24]. Decreases in kidney function typically do not occur until adulthood in those with ADPKD [24]. The prevalence of overweight and obesity has also increased in the ADPKD community.

\section{Polycycstic Kidney Disease affects Polycystin 1 and Polycystin 2 proteins}

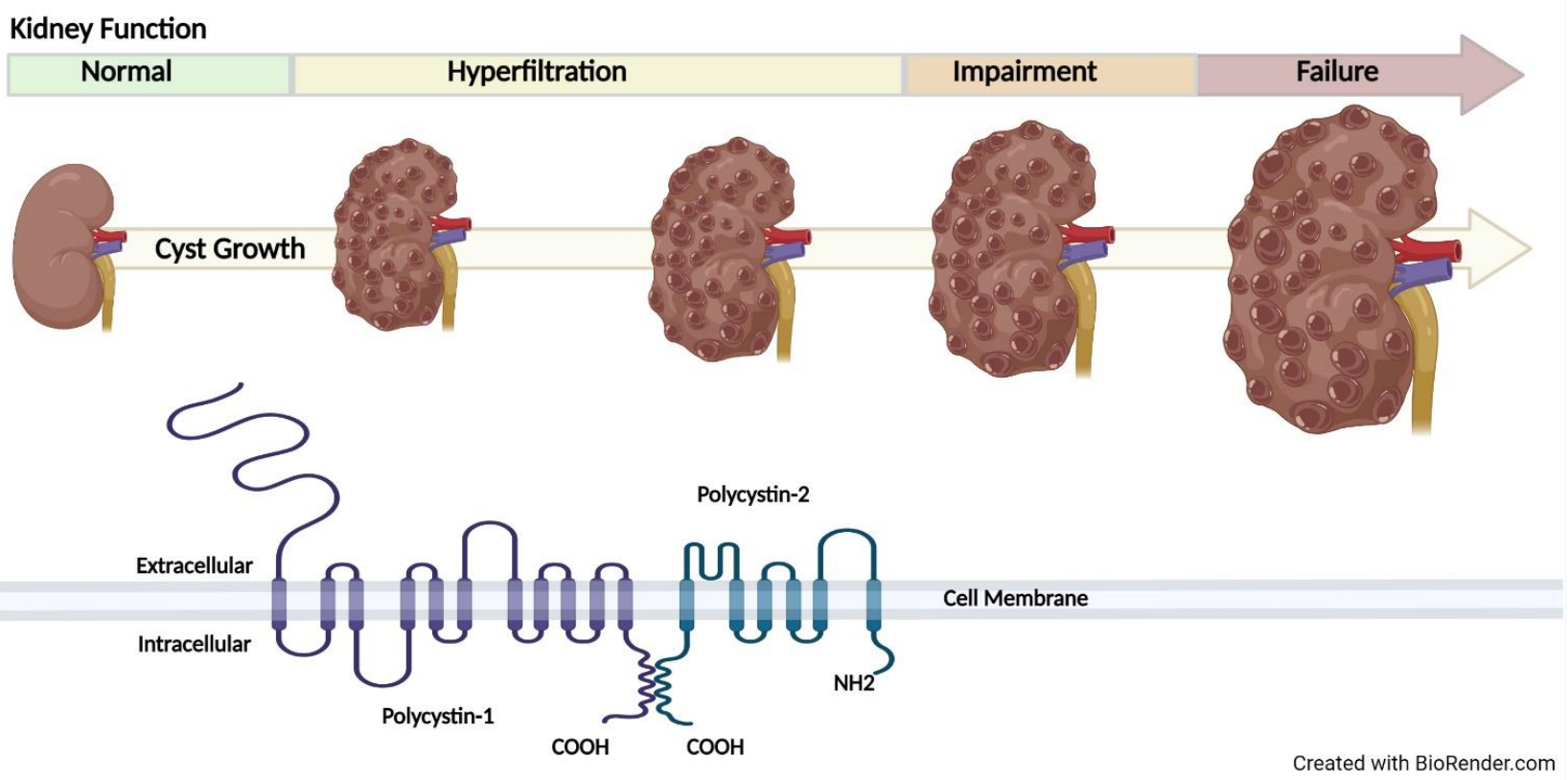

Figure 1. Autosomal polycystic kidney disease (ADPKD) progression and genetic mutations. ADPKD increases total kidney volume from the initiation and proliferation of kidney cysts, causing reductions in kidney function leading to end-stage kidney disease. Polycystin 1 and Polycystin 2 proteins are affected in ADPKD.

In the HALT Progression of Polycystic Kidney Disease Study A (HALT-PKD Study A), which included individuals in the United States averaging 37 years of age with early-stage ADPKD, $62.7 \%$ of participants were overweight or obese $[26,27]$. The average BMI in this trial was $27.1 \mathrm{~kg} / \mathrm{m}^{2}[26,27]$. The prevalence of overweight and obesity continue to rise, impacting many populations, including those with CKD and ADPKD.

This narrative review will summarize supporting data in humans in the general population, CKD population, and ADPKD population in relation to obesity. We will explore the potential mechanistic evidence related to the role of adipose tissue in kidney disease. Finally, we will discuss the potential effects of lifestyle modifications that have been studied or are currently under investigation. 


\section{Epidemiological Data on BMI and Kidney Disease}

\subsection{General Population}

Obesity increases the risk for kidney disease in the general population [28]. Obesity classified by BMI, increased waist circumference, and increased visceral adipose tissue are associated with elevated albuminuria in the general population [29-32]. After adjusting for potential confounders, higher BMI is associated with increased risk of CKD $[18,33,34]$, reduced estimated glomerular filtration rate (eGFR) [35], decline in kidney function (eGFR slope) [36], and incidence of ESKD [19,20,37] in the general population. A higher BMI at the baseline and increases in BMI over 14 years are associated with a greater risk of CKD [33]. Larger waist circumference is also associated with ESKD, even after adjustment for BMI [22]. Pinto-Sietsma et al. found lean, overweight, and obese subjects with central fat distribution were all at risk for diminished filtration [29]. Central fat distribution has been defined as a waist-hip ratio of $\geq 0.9$ for men and $\geq 0.8$ for women $[29,38]$. Collectively, this evidence supports that fat distribution may elevate the risk for kidney disease even more than BMI.

\subsection{Chronic Kidney Disease}

A greater prevalence of overweight and obesity has been observed in males aged 45-64 years with CKD stages $3 \mathrm{~b}$ and $4\left(\leq 44 \mathrm{~mL} / \mathrm{min} / 1.73 \mathrm{~m}^{2}\right)$ when compared to females and to CKD stages $1-3 \mathrm{a}\left(\geq 45 \mathrm{~mL} / \mathrm{min} / 1.73 \mathrm{~m}^{2}\right)$ [39]. Higher BMI is associated with increased risk for incident of CKD and advanced CKD (Stage 4-5; eGFR $\leq 29 \mathrm{~mL} / \mathrm{min} / 1.73 \mathrm{~m}^{2}$ ) [18,33,34,40]. A male-sex-specific association between increased BMI and CKD has been noted in several studies [19,39,41,42]. Notably, BMI may reflect visceral fat more effectively in males when compared to females $[43,44]$. In addition, the occurrence of CKD progression, as measured by the rate of eGFR decline per year (>1 mL/min/1.73 $\mathrm{m}^{2} /$ year), was greater in those with overweight and obese when compared to normal-weight CKD patients [45].

However, there have been several studies that have found no association between BMI and progression of disease in individuals with CKD [23,46-49]. Commonly referred to as the "obesity paradox", epidemiological studies have demonstrated a lower relative risk of death in patients who are overweight or obese with ESKD, stroke, and heart failure, among other conditions [50-56]. Specifically, dialysis patients who are overweight or obese have a decreased mortality risk [53]. Lu et al. identified a U-shaped association between BMI and risk of kidney disease progression in a large cohort of United States Veterans, demonstrating that those with overweight and mild obesity (BMI $25-35 \mathrm{~kg} / \mathrm{m}^{2}$ ) had more favorable clinical outcomes [36]. This phenomenon might be explained by the inherent complexity of chronic diseases, unmeasured risk factors, or bias related to participant selection. There are constraints to using BMI in that it does not account for muscle mass, peripheral and abdominal adipose tissue mass, and bone; consequently, the results should be considered under these limitations [36]. However, globally BMI is the primary measurement to evaluate and define obesity [2]. Molnar et al. found hemodialysis patients with lower BMI or muscle mass and/or unintentional weight or muscle loss had higher mortality [54]. Interestingly, the waist to hip ratio and waist circumference, but not BMI, was associated with mortality in a cohort of patients with CKD and ESKD [43,44]. Additionally, those with CKD who were in the normal BMI category with central obesity had an increased risk of coronary artery calcification [57]. Collectively, these observations again underscore that central obesity might be key in disease development and progression.

\subsection{Autosomal Dominant Polycystic Kidney Disease}

Distinct from other etiologies of CKD, total kidney volume (TKV), often adjusted by height, has been identified as the best biomarker for ADPKD progression, particularly in early-stage disease [58,59]. In addition, Mayo imaging classification helps predict loss of kidney function based on TKV, age, height, and sex [59]. HALT-PKD Study A was a randomized, double-blind, placebo-controlled study in non-diabetic patients with early- 
stage ADPKD [26]. In HALT-PKD study A, baseline BMI was significantly associated with baseline height-adjusted total kidney volume (htTKV) in men only [60]. Body-surface area was also an independent predictor of baseline htTKV and baseline eGFR in the HALT Studies [60].

In a fully adjusted model accounting for age, sex, race/ethnicity, group randomization, systolic blood pressure, eGFR, urinary albumin excretion, baseline TKV, baseline liver volume, serum class, and mutation class, a higher BMI was associated with a greater annual percent change in TKV in patients with early-stage ADPKD participating in HALT study A [61]. Obesity was also associated with a faster decline in eGFR [61]. These results were subsequently confirmed in individuals with early-stage ADPKD participating in the Tolvaptan Efficacy and Safety in the Management of Autosomal Dominant Polycystic Kidney Disease and Its Outcomes (TEMPO 3-4) trial. After adjustment for age, sex, race/ethnicity, group randomization, systolic blood pressure, serum glucose, baseline eGFR, urinary microalbumin, plasma copeptin, and mutation class, a higher BMI was again associated with a greater annual change in TKV [27]. Notably, the efficacy of tolvaptan was independent of BMI [27]. Of importance, in those with ADPKD, enlarged kidneys may contribute considerably to overall body weight, which may impact BMI calculations, expanding the limitations of BMI discussed previously [62]. However, in the analyses from HALT study A and TEMPO 3:4, BMI was calculated after subtracting the contribution of the kidneys to total body weight, thus controlling for this factor.

The epidemiological data present a strong case overall that overweight and obesity, as measured by BMI, may increase the risk of incident kidney disease and progression, although these studies are observational and there are inherent limitations. Specifically, the ADPKD studies present strong evidence that overweight and obesity are risk factors for disease progression measured by TKV. The mixed evidence in the CKD population, particularly involving the association of BMI with eGFR, may be due to the inability to account for body composition, fat distribution, and other unmeasured risk factors in the CKD population. This underscores the importance that central body fatness is a stronger predictor of overall disease risk when compared to overall body size [63,64].

\section{Potential Role of Adipose Tissue}

Adipose tissue is important in helping to maintain lipid and glucose homeostasis [65]. However, obesity and increased accumulation of adipose tissue result in a pro-inflammatory, hyperlipidemic, and insulin-resistant environment. This dysfunctional adipose tissue can contribute to type 2 diabetes and promote cardiovascular disease [66]. Excessive adipose tissue has the potential to be even more harmful to individuals with ADPKD because of the known metabolic alterations linked to the genetic disease [67].

\subsection{Types and Distribution of Adipose Tissue}

Obesity increases total adipose tissue. When in excess, adipose tissue becomes displaced, producing fat deposits not only surrounding the kidneys but also other vital organs. Visceral adipose tissue is hormonally active and has distinct biochemical attributes that impact various normal and pathological processes in the human body [68]. In humans, the only measurements that can produce direct measures of cross-sectional areas or volumetric measures of visceral adipose tissue are through a computerized tomography (CT) scan or magnetic resonance imaging [68]. Visceral adipose tissue is metabolically active and stimulates the release of fatty acids into circulation. Accumulation of visceral fat or visceral obesity leads to a cascade of negative events that promote metabolic syndrome including hyperinsulinemia, systematic inflammation, and dyslipidemia [69]. Both increases in visceral and subcutaneous adipose tissue were associated with a decrease in eGFR (cystatin-based equation) in the individuals from the Framingham Offspring Study (general population) who underwent abdominal CT scans [70]. The location of the adipose tissue, as well as the type of adipose tissue, determines the impact it will have on biochemical processes. 
Adipose tissue can be classified into three subsets: white, brown, and beige adipose tissue. About eighty percent of adipose tissue found in lean healthy subjects is subcutaneous white adipose tissue (WAT) [71]. In humans, brown fat found near the regions of the spine accounts for about $2 \%$ of total fat [72]. Beige adipose tissue comprises both white and brown adipose tissue. Genetics may also influence WAT distribution [72]. Recently, Fas Binding Factor 1 (FBF1) deficiency has been shown to stimulate beiging and beneficial growth of WAT [73]. Interestingly, FBF1 controlled the beiging program via a cilia-specific, A-kinase anchoring protein (AKAP9)-dependent, protein kinase A (PKA) signaling, supporting a central role for primary cilia in the fate determination of preadipocytes and the generation of metabolically healthy adipose tissue [73].

In those without obesity, WAT is a vital energy source in that it acts as a lipid storage reserve. However, obesity causes WAT to become metabolically dysfunctional [74]. Perinephric adipose tissue (PAT) is a type of WAT that encircles the kidney and supports kidney function [75]. In the Framingham Heart Study, individuals with higher PAT had a higher risk of hypertension, even with adjustment for BMI and visceral fat [76]. During tumorigenesis of clear cell renal cell carcinoma (ccRCC), cells preferentially invade PAT, a process associated with poor prognosis. The cells secrete a parathyroid-hormone-related protein (PTHrP), which promotes the browning of PAT by PKA activation, and the excess release of lactate mediated by thermogenesis, enhancing ccRCC growth. Inhibiting the ccRCC-adipocyte feedback prevents cell growth, invasion, and metastasis [77]. This evidence could potentially be applied to an ADPKD model to suppress the proliferation of kidney cysts.

\subsection{Harmful Effects of Adipose Tissue}

Adipose tissue releases adipokines, growth factors, pro-inflammatory cytokines, and chemotactic cytokines [78]. Adipokines secrete hormones such as leptin [79], omentin [80], adiponectin [81], resistin [82,83], and fibroblast growth factor 21 [84], which are influenced by weight gain and increased adipose tissue accumulation (Figure 2).

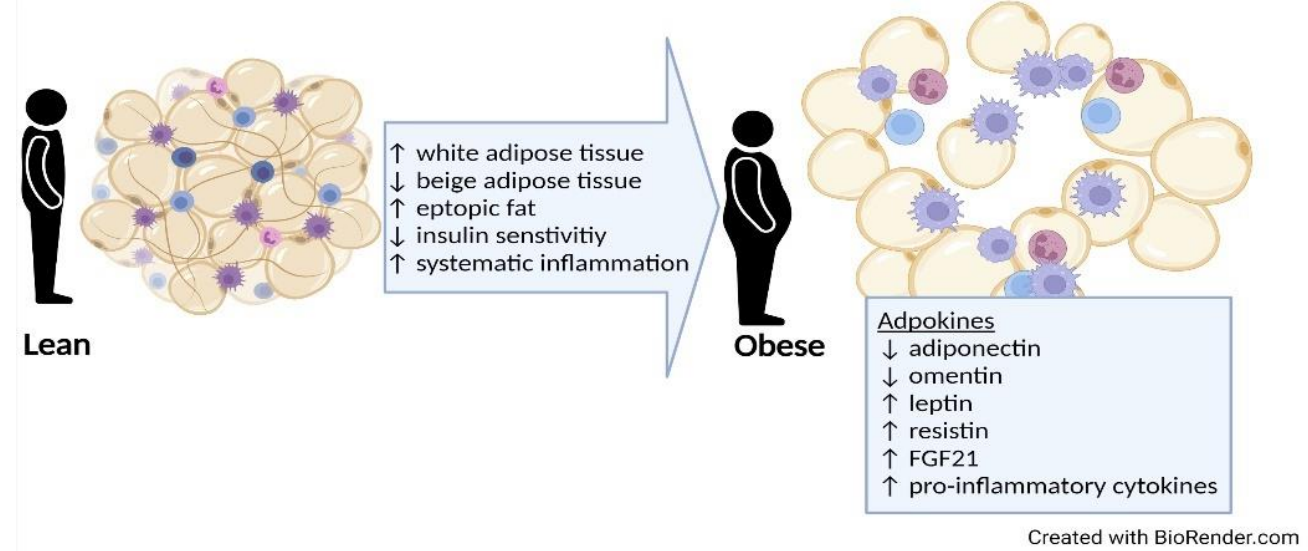

Figure 2. Harmful effects of increased adipose tissue with weight gain. With weight gain there is an increase in total adipose tissue (white and brown adipose tissue); excessive accumulation of adipose tissue causes insulin sensitivity and systematic inflammation. The increase in adipokines leads to altered hormone secretion and pro-inflammatory cytokine production. Abbreviation: FGF21, fibroblast growth factor 2 .

Evidence suggests that the elevations in pro-inflammatory cytokines observed in obesity, including interleukin 6 (IL-6), tumor necrosis factor-alpha (TNF- $\alpha$ ), monocyte chemoattractant protein-1 (MCP-1), and serum amyloid, can be reduced via weight loss [85-88]. Epicardial adipose tissue thickness measured via echocardiography was independently associated with highly sensitive C-reactive protein (hs-CRP) concentrations in normotensive ADPKD patients with preserved renal function [89]. In general, reductions in adipose 
tissue in individuals with ADPKD who are overweight and obese could potentially induce a shift in cytokines and hormones, reducing the effects of ADPKD-associated metabolic dysfunction.

\section{Pathways Relevant to Obesity and ADPKD}

Several signaling pathways promote inflammation and influence cystogenesis, including the c-Jun N-terminal kinase and the inhibitor of kappa B kinase beta-nuclear factor-kappa B pathways [90]. In addition, many hormones and cytokines altered with obesity may influence ADPKD progression, including increased levels of insulin, insulin-like growth factor 1 (IGF-1), leptin, TNF- $\alpha$, and IL-6, as well as decreased adiponectin [85-88]. These alterations can promote an increase in the activity of the phosphatidylinositol 3-kinase (PI3K)/Akt signal pathway, which impacts cell survival and growth [91].

Both leptin and adiponectin also act through the AMP-activated protein kinase (AMPK) pathway [92]. Studies have demonstrated that adiponectin activates AMPK via adiponectin receptor 1 , and AMPK is known to inhibit the mammalian target of rapamycin (mTOR) pathway $[93,94]$. Cytokines secreted from visceral adipose tissue promote a pro-tumorigenic environment, which may also be applicable to ADPKD. Interleukin-6 (IL-6) can activate the signal transducer and activator of transcription 3 (STAT3) and extracellular signal-regulated kinase (ERK) signaling, which are known to be increased in PKD [95]. TNF- $\alpha$ initiates cell signaling through tumor necrosis factor receptor 1 (TNRF1), activating TNFR1-associated death domain (TRADD), TRN receptor-associated factor-2 (TRAF2), and a receptor-interacting protein (RIP). The pathway leads to an active NF-кB essential modulator (NEMO), which translocates to the nucleus to promote the production of pro-inflammatory genes [96]. Insulin binds to the insulin receptor (IR), activating receptor tyrosine kinase, which allows binding of insulin receptor substrates (IRS). IRS then stimulates cell proliferation via the PI3K-AKT system, the mammalian target of rapamycin (mTOR), and the MAPK systems [97]. Saturated fatty acids (SFAs) can bind to Fetuin-A, which is an endogenous ligand of toll-like receptor 2 (TLR2) or TLR4, and invokes transcription of interferon regulatory factor 3 (IRF3) [98]. SFAs are the main non-esterified fatty acid (NEFA) in the circulation of obese subjects [98]. SFAs activate an inflammatory response via TLR4 signaling, serving as a connection between fatty acid excess and chronic low-grade inflammation [98]. All these signaling pathways play a role in inflammation and cell proliferation (Figure 3).

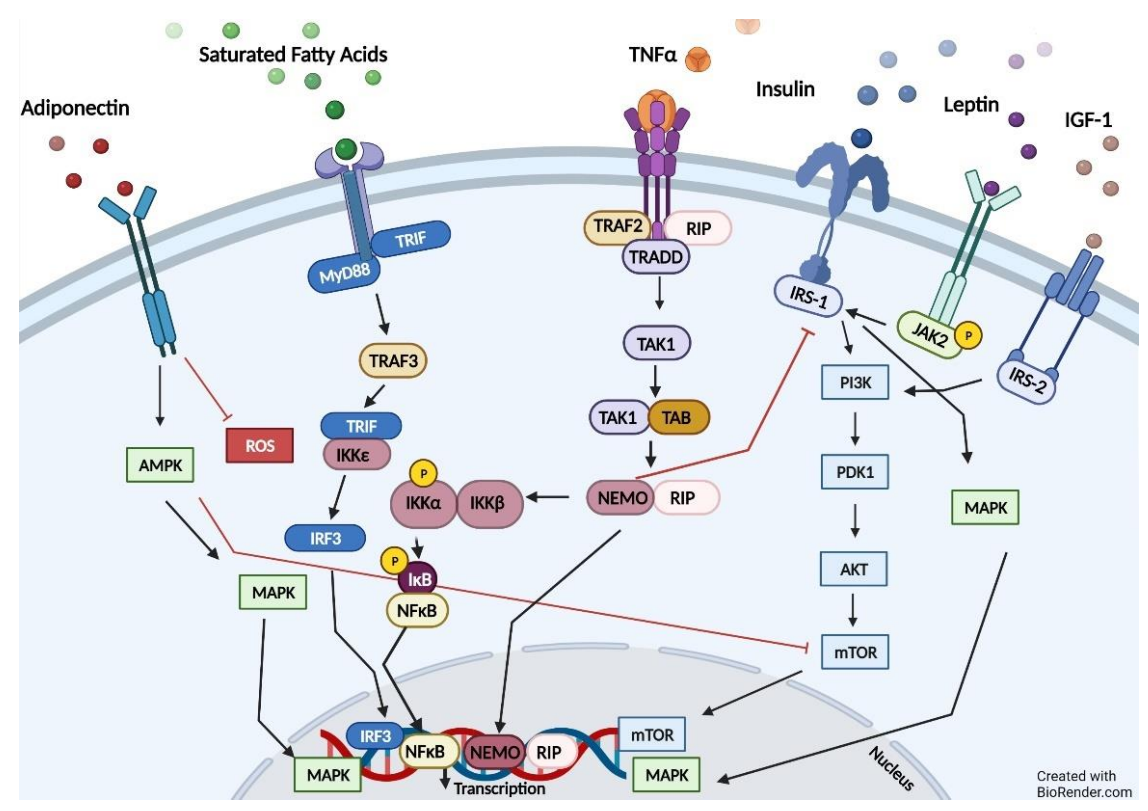

Figure 3. Signaling pathways impacted by obesity. Obesity leads to the activation of inflammatory 
signaling pathways in metabolic cells through several pathways. The increase in pro-inflammatory cytokines can then lead to intensified receptor activation as the cytokine signals combine with excess nutrients, especially fatty acids. (Abbreviations: AMPK, AMP-activated protein kinase; MAPK, mitogen-activated protein kinase; ROS, reactive oxygen species; MyD88, myeloid differentiation primary response 88 ; TRIF, TIR-domain-containing adapter-inducing interferon- $\beta$; TRAF3, TNF receptor associated factor 3; IRF3, interferon regulatory factor 3; IKKє, IkappaB kinase $\epsilon$; IKK $\beta$, IkappaB kinase $\beta$; IKK $\alpha$, IkappaB kinase $\alpha$; IкB, nuclear factor-кB; NFkB, nuclear factor kappa B; TNF $\alpha$, tumor necrosis factor $\alpha$; TRAF2, TNF receptor associated factor 2; RIP, receptor-interacting protein; TRADD, tumor necrosis factor receptor type 1 associated death domain protein; TAK1, transforming growth factor- $\beta$-activated kinase; TAB1, TAK-1-binding protein; NEMO, NF- $\mathrm{BB}$ essential modulator; IRS-1, insulin receptor substrate-1; IRS-2, insulin receptor substrate-2; IGF-1, insulin-like growth factor 1; JAK2, janus-activated kinase 2; PI3K, phosphoinositide 3-kinases; PDK1, pyruvate dehydrogenase kinase 1 ; AKT, protein kinase $\mathrm{B}$; mTOR, mammalian target of rapamycin).

\section{Impaired Fatty Oxidation}

There is also evidence of impaired fatty acid oxidation in Pkd1 mutant mice [98]. However, lowering the lipid content in chow modified cystic disease by correcting the fatty acid oxidation impairment in mice [99]. Female mice had a less severe kidney phenotype, which was associated with protection from alterations in lipid metabolism compared to males [98]. In HALT Study A, there was a significant positive association between two large chain triglycerides (Triglyceride(51:3) $[\mathrm{M}+\mathrm{K}]+$ and Triglyceride(53:3) $[\mathrm{M}+\mathrm{K}]+$ ) and htTKV at baseline [100]. In the HALT studies, there was also evidence of altered fatty acid metabolism, including lipoxygenase pathways (LOX) [101]. These findings provide evidence that ADPKD may further be exacerbated with obesity from the inability to oxidize fatty acids.

\section{Weight Loss and Kidney Function}

\subsection{General Population and Other Disease Profiles}

In the general population, there have been numerous randomized control trials assessing weight-loss interventions. A recent meta-analysis concluded that weight-reducing diets, generally low in overall fat and saturated fat, with or without exercise advice or programs, have the potential to reduce premature all-cause mortality in adults with obesity [102]. In adults with type 2 diabetes, a weight loss of $>5 \%$ appears essential for favorable effects on $\mathrm{HbA1c}$, lipids, and blood pressure [103]. In a prospective 3-year cohort study, rapid weight loss was correlated with reduced kidney function measured by eGFR in normalweight, healthy, non-diabetic males, but improved kidney function in males who were overweight [104].

\subsection{Chronic Kidney Disease}

A systematic review consisting of five controlled and eight uncontrolled trials concluded that weight loss is associated with decreased proteinuria and microalbuminuria in those with CKD [105]. Mechanisms of how weight loss via diet, physical activity, or pharmaceuticals reduces proteinuria may include enhanced blood pressure control, an improved lipid profile, increased insulin sensitivity, reduced leptin concentrations, reduced glomerular hyperfiltration, diminished RAAS activation, and an overall decrease in inflammatory and oxidative stress markers/pathways [106]. In another systematic review evaluating weight loss and kidney function in CKD patients, weight loss, especially via surgical interventions, improved proteinuria, albuminuria, and normalized GFR [107]. Lifestyle interventions completed in obese CKD patients have included primarily caloric restriction diet plans with or without an exercise prescription [108-113]. These lifestyle interventional studies reduced BMI, proteinuria, and albuminuria [56-59]. Additionally, a third recent systematic review concluded that non-surgical weight-loss interventions are effective in reducing body weight and LDL cholesterol in overweight and obese adults with CKD [114]. Overall, lifestyle interventions that invoke weight loss appear to have 
beneficial effects in adults with CKD; however, more research is needed, including larger and longer trials evaluating the effects of weight loss on CKD progression.

\subsection{Autosomal Dominant Polycystic Kidney Disease}

The kidneys rely primarily on fatty acid oxidation (FAO) via aerobic glycolysis to produce adenosine triphosphate and have high metabolic demand, especially in the proximal tubule. A defect in fatty acid oxidation can lead to deleterious effects on the kidneys [115]. Metabolic reprogramming, including altered substrate metabolism, compromised autophagy, and mitochondrial impairment in ADPKD, have been reviewed previously [67]. The majority of pathways affected by ADPKD also have extrarenal implications, making targeted drug therapy more of a challenge [116]. However, altered cellular pathways associated with obesity in individuals with ADPKD could potentially be targeted via lifestyle interventions that induce weight loss as a potential avenue to improve metabolic health (Figure 4).

\section{Obesity has been linked to Faster Diesease Progression}

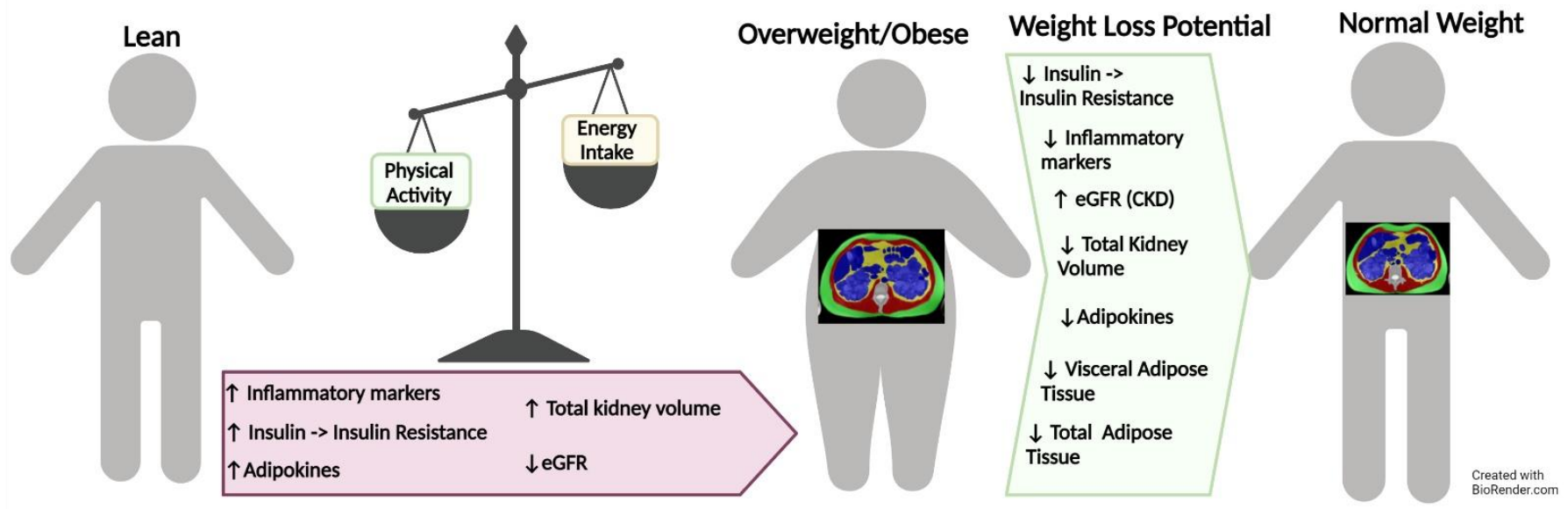

Figure 4. Weight loss interventions may help slow ADPKD disease progression. Obesity has been shown to have negative consequences on disease progression in those with ADPKD. Weight loss may have the potential to reduce total kidney volume, total adiposity, and metabolic and proinflammatory responses.

\section{Weight Loss Interventions and Kidney Function in ADPKD}

\subsection{Physical Activity Interventions}

Collectively, large epidemiological studies and several randomized controlled trials, including both the general population and those with CKD, provide evidence that increased physical activity can reduce the risk of mortality [117-120]. The recommendations for frequency, intensity, time, and type of exercise are still being developed for those with CKD [121]. General recommendations listed for the CKD population include gradually increasing physical activity to the following: aerobic exercise 3-5 days/week for 20-60 min, resistance training 2-3 days/week, and flexibility 2-3 days/week [121]. Another recommendation specific to the PKD population has been to avoid hard contact sports, such as rugby or American football, due to the potential of kidney cysts rupturing from impact [122]. Currently, only one ongoing clinical trial (NCT04907799) involves a dietary intervention ( $30 \%$ daily caloric reduction) as well as physical activity prescription (300 min per week of moderate-intensity exercise) in participants with ADPKD. This trial will provide important insight into the feasibility of an intervention focused on physical activity in APDKD. 


\subsection{Dietary Interventions}

The dietary interventions proposed and currently being evaluated in humans have included caloric restriction, intermittent fasting, time-restricted eating, and a ketogenic diet (Table 1) [123-126]. The foundation of these studies is based on murine models demonstrating the benefits of caloric restriction $[127,128]$, time-restricted feeding $[128,129]$, and ketogenic diets [129] on PKD progression, as reviewed elsewhere recently [123]. In addition, one retrospective case series including 131 PKD patients assessed the role of ketogenic dietary interventions via survey, questionnaire-based interviews, and retrospective medical data to assess potential beneficial or adverse effects. Although there are major limitations to this observational study, including selection bias, the investigators found patients' experience with ketogenic diets were overall beneficial, safe, and feasible from the interviews [130]. Only one trial, which included both daily caloric restriction and intermittent fasting, has evaluated abdominal adiposity via magnetic resonance imaging (MRI). After the 1-year interventions, there were significant reductions in abdominal visceral adipose and total adipose tissue [124]. Slowed kidney growth, as measured by the annual change in htTKV, was associated with body weight and visceral adiposity loss regardless of the intervention [128]. These findings suggest fat distribution, specifically central obesity resulting in an accumulation in visceral adipose tissue, may play a crucial role in ADPKD progression. The primary outcome in the ongoing clinical trial evaluating daily caloric restriction (NCT04907799) is change in htTKV and is currently the largest on-going dietary interventional study in those ADPKD. This trial will also provide insight into the role of change in visceral and subcutaneous adipose tissue in ADPKD progression. 
Table 1. Dietary interventions, weight loss, and outcomes in those with ADPKD.

\begin{tabular}{|c|c|c|c|c|c|}
\hline Intervention & Study Design & Length $(n)$ & $\begin{array}{l}\text { Baseline BMI } \\
\left(\mathrm{kg} / \mathrm{m}^{2}\right) \text { or Inclusion }\end{array}$ & Weight Loss & Kidney Outcomes \\
\hline $\begin{array}{l}\text { Caloric Restriction } \\
\text { (34\% reduction in caloric intake, } \\
\text { NCT03342742) } \\
\text { Status: Complete [124] }\end{array}$ & $\begin{array}{l}\text { Randomized, double blind, parallel } \\
\text { assignment, two experimental } \\
\text { arms }\end{array}$ & $\begin{array}{l}\text { 12-months } \\
(n=15)\end{array}$ & $34.6 \pm 5.1$ & $\begin{array}{l}\text { 3-months: }-7.1 \pm 4.2 \% \\
\text { 12-months: }-9.1 \pm 6.0 \%\end{array}$ & \multirow{2}{*}{$\begin{array}{l}\text { Annual } \% \text { change in htTKV was } \\
\text { highly correlated with } \% \text { change } \\
\text { in weight }(\mathrm{r}=0.68, p=0.001) \text { and } \\
\text { change in BMI at } 12 \text {-months }(\mathrm{r}= \\
0.63, p<0.01)\end{array}$} \\
\hline $\begin{array}{l}\text { Intermittent Fasting } \\
(20 \% \text { reduction on three } \\
\text { non-consecutive days per week, } \\
\text { NCT03342742) } \\
\text { Status: Complete [124] }\end{array}$ & $\begin{array}{l}\text { Randomized, double blind, parallel } \\
\text { assignment two experimental arms }\end{array}$ & $\begin{array}{l}\text { 12-months } \\
(n=13)\end{array}$ & $34.8 \pm 5.1$ & $\begin{array}{l}\text { 3-months: }-5.5 \pm 3.3 \% \\
\text { 12-months: }-4.9 \pm 5.6 \%\end{array}$ & \\
\hline $\begin{array}{l}\text { Ketogenic Diet (lipids } 65 \% \text {, } \\
\text { proteins } 30 \% \text {, and carbohydrate } 5 \% \\
\text { total caloric intake, modified } \\
\text { Atkins diet) } \\
\text { Status: Complete [125] }\end{array}$ & Single-arm interventional pilot & $\begin{array}{l}\text { 3-months } \\
(n=3)\end{array}$ & $25.3 \pm 1.4$ & $\begin{array}{l}\text { Hypocaloric ketogenic diet } \\
\text { invoked weight loss } 1-4.2 \mathrm{~kg} \text { in } \\
\text { those who were overweight }\end{array}$ & eGFR did not change \\
\hline $\begin{array}{l}\text { Caloric Restriction ( } 30 \% \text { reduction } \\
\text { in caloric intake and increased } \\
\text { physical activity, NCT04907799) } \\
\text { Status: On-going }\end{array}$ & $\begin{array}{l}\text { Randomized, double-blind, } \\
\text { parallel assignment one } \\
\text { experimental arm, one control arm }\end{array}$ & $\begin{array}{l}\text { 24-months } \\
(n=126)\end{array}$ & $25-45$ & $\begin{array}{l}\text { Secondary outcome change in } \\
\text { abdominal adiposity }\end{array}$ & $\begin{array}{l}\text { Primary outcome change in } \\
\text { htTKV }\end{array}$ \\
\hline $\begin{array}{l}\text { Time-Restricted Eating (food intake } \\
\text { restricted to an 8-h window, } \\
\text { NCT04534985). } \\
\text { Status: On-going }\end{array}$ & $\begin{array}{l}\text { Randomized, double-blind, } \\
\text { parallel assignment one } \\
\text { experimental arm, one active } \\
\text { comparator }\end{array}$ & $\begin{array}{l}\text { 12-months } \\
(n=30)\end{array}$ & $25-45$ & $\begin{array}{l}\text { Secondary outcomes change in } \\
\text { body weight, abdominal } \\
\text { adiposity, and body composition }\end{array}$ & $\begin{array}{l}\text { Secondary outcome change } \\
\text { in htTKV }\end{array}$ \\
\hline $\begin{array}{l}\text { Ketogenic } \\
\text { Diet (High fat, moderate protein, } \\
\text { very low carbohydrate }<20 \mathrm{~g} \text { per } \\
\text { day, NCT04680780) } \\
\text { Status: On-going }\end{array}$ & $\begin{array}{l}\text { Randomized, parallel assignment, } \\
\text { two experimental arms, and one } \\
\text { control arm }\end{array}$ & $\begin{array}{l}\text { 3-months } \\
(n=21)\end{array}$ & $18.6-34.9$ & $\begin{array}{l}\text { Secondary outcome change } \\
\text { in BMI }\end{array}$ & $\begin{array}{l}\text { Secondary outcome change } \\
\text { in TKV }\end{array}$ \\
\hline $\begin{array}{l}\text { Water Fasting (water fasting on } 3 \\
\text { consecutive days within the first } 14 \\
\text { days of each month, NCT04680780) } \\
\text { Status: On-going }\end{array}$ & $\begin{array}{l}\text { Randomized, parallel assignment, } \\
\text { two experimental arms, and one } \\
\text { control arm }\end{array}$ & $\begin{array}{l}\text { 3-months } \\
(n=21)\end{array}$ & $18.6-34.9$ & $\begin{array}{l}\text { Secondary outcome change } \\
\text { in BMI }\end{array}$ & $\begin{array}{l}\text { Secondary outcome change } \\
\text { in TKV }\end{array}$ \\
\hline
\end{tabular}


Table 1. Cont.

\begin{tabular}{|c|c|c|c|c|c|}
\hline Intervention & Study Design & Length $(n)$ & $\begin{array}{l}\text { Baseline BMI } \\
\left(\mathrm{kg} / \mathrm{m}^{2}\right) \text { or Inclusion }\end{array}$ & Weight Loss & Kidney Outcomes \\
\hline $\begin{array}{l}\text { Acute fasting for } 72 \mathrm{~h} \text { or intake of a } \\
\text { ketogenic diet for } 14 \text { days } \\
\text { (NCT04472624) } \\
\text { Status: Complete (results } \\
\text { not posted) }\end{array}$ & $\begin{array}{l}\text { Non-randomized (participant } \\
\text { selected experimental arm), } \\
\text { parallel assignment }\end{array}$ & $\begin{array}{l}72 \mathrm{~h} \text { (fasting) or } 14 \\
\text { days (ketogenic } \\
\text { diet) } \\
(n=10)\end{array}$ & $18-35$ & $\begin{array}{l}\text { Secondary outcome absolute and } \\
\text { relative change in weight }\end{array}$ & $\begin{array}{l}\text { Primary outcome relative } \\
\text { difference in TKV immediately } \\
\text { before and after the ketonic state } \\
\text { [Time Frame: Visit 2: 2-4 Weeks } \\
\text { after enrolment; Visit 3: 3-21 } \\
\text { days after Visit 2] }\end{array}$ \\
\hline $\begin{array}{l}\text { Ketogenic Diet }[4-6 \% \\
\text { carbohydrates, } 25-30 \% \text { proteins, } \\
\text { and } 60-70 \% \text { lipids; modified } \\
\text { Atkins diet], or a balanced } \\
\text { normocaloric diet }[55-60 \% \\
\text { carbohydrates, } 10-15 \% \text { proteins, } \\
25-30 \% \text { lipids]. } \\
\text { Status: On-going [126] }\end{array}$ & $\begin{array}{l}\text { Randomized, parallel group, two } \\
\text { experimental arms }\end{array}$ & $\begin{array}{l}12 \text { months } \\
(n=90)\end{array}$ & $>20$ & $\begin{array}{l}\text { Caloric intake will be adjusted } \\
\text { for participants to remain } \\
\text { weight stable }\end{array}$ & Primary outcome change in TKV \\
\hline
\end{tabular}




\section{Novel Future Direction and Clinical Implications}

Drug development directly targeting cyst growth to delay the progression of ADPKD remains challenging. Overweight and obesity in those with ADPKD may promote further metabolic dysfunction, accelerating disease progression. Interventions that invoke weight loss and reduce adipose tissue are of interest to prevent or reverse the metabolic consequences of obesity in those with ADPKD. Mechanistic studies evaluating the role of adipose tissue in disease progression are needed to develop targeted treatments and solutions to this increasing health concern.

Author Contributions: C.S. and K.N. reviewed the literature and contributed to the preparation of this narrative review. All authors have read and agreed to the published version of the manuscript.

Funding: C.S. is supported by NIDDK (grant 5T32DK007135-46). This work was supported by NIDDK (grant R01DK129259) and the PKD Foundation (241G20a), to K.N.

Acknowledgments: Figures were created with BioRender.com (accessed on 23 February 2022).

Conflicts of Interest: C.S. has no conflict of interest to disclose. K.N. has performed investigator-initiated research completed in collaboration with Otsuka Pharmaceutical Development \& Commercialization.

\section{References}

1. Fruh, S.M. Obesity: Risk factors, complications, and strategies for sustainable long-term weight management. J. Am. Assoc. Nurse Pract. 2017, 29, S3-S14. [CrossRef] [PubMed]

2. Hruby, A.; Hu, F.B. The Epidemiology of Obesity: A Big Picture. Pharmacoeconomics 2015, 33, 673-689. [CrossRef]

3. Stevens, G.A.; Singh, G.M.; Lu, Y.; Danaei, G.; Lin, J.K.; Finucane, M.M.; Bahalim, A.N.; McIntire, R.K.; Gutierrez, H.R.; Cowan, M.; et al. National, regional, and global trends in adult overweight and obesity prevalences. Popul. Health Metr. 2012, 10, 22. [CrossRef] [PubMed]

4. $\quad$ Baskin, M.L.; Ard, J.; Franklin, F.; Allison, D.B. Prevalence of obesity in the United States. Obes. Rev. 2005, 6, 5-7. [CrossRef]

5. Flegal, K.M.; Carroll, M.D.; Ogden, C.L.; Curtin, L.R. Prevalence and Trends in Obesity Among US Adults, 1999-2008. J. Am. Med. Assoc. 2010, 303, 235-241. [CrossRef] [PubMed]

6. Valderas, J.M.; Starfield, B.; Sibbald, B.; Salisbury, C.; Roland, M. Defining comorbidity: Implications for understanding health and health services. Ann. Fam. Med. 2009, 7, 357-363. [CrossRef]

7. Chalmers, L.; Kaskel, F.J.; Bamgbola, O. The Role of Obesity and Its Bioclinical Correlates in the Progression of Chronic Kidney Disease. Adv. Chronic Kidney Dis. 2006, 13, 352-364. [CrossRef] [PubMed]

8. Hall, J.E.; Brands, M.W.; Dixon, W.N.; Smith, M.J., Jr. Obesity-induced hypertension. Renal function and systemic hemodynamics. Hypertension 1993, 22, 292-299. [CrossRef]

9. Hall, J.E.; Crook, E.D.; Jones, D.W.; Wofford, M.R.; Dubbert, P.M. Mechanisms of obesity-associated cardiovascular and renal disease. Am. J. Med. Sci. 2002, 324, 127-137. [CrossRef]

10. Vaes, B.; Beke, E.; Truyers, C.; Elli, S.; Buntinx, F.; Verbakel, J.Y.; Goderis, G.; Van Pottelbergh, G. The correlation between blood pressure and kidney function decline in older people: A registry-based cohort study. British Med. J. Open. 2015,5 , e007571. [CrossRef]

11. Hall, M.E.; do Carmo, J.M.; da Silva, A.A.; Juncos, L.A.; Wang, Z.; Hall, J.E. Obesity, hypertension, and chronic kidney disease. Int. J. Nephrol. Renov. Dis. 2014, 7, 75-88. [CrossRef] [PubMed]

12. Alvarez, G.E.; Beske, S.D.; Ballard, T.P.; Davy, K.P. Sympathetic Neural Activation in Visceral Obesity. Circ. 2002, 106, 2533-2536. [CrossRef] [PubMed]

13. Esler, M.; Rumantir, M.; Wiesner, G.; Kaye, D.; Hastings, J.; Lambert, G. Sympathetic nervous system and insulin resistance: From obesity to diabetes. Am. J. Hypertens. 2001, 14, 304S-309S. [CrossRef]

14. Abate, N.I.; Mansour, Y.H.; Tuncel, M.; Arbique, D.; Chavoshan, B.; Kizilbash, A.; Howell-Stampley, T.; Vongpatanasin, W.; Victor, R.G. Overweight and sympathetic overactivity in black Americans. Hypertens. 2001, 38, 379-383. [CrossRef] [PubMed]

15. Bloomfield, G.L.; Sugerman, H.J.; Blocher, C.R.; Gehr, T.W.; Sica, D.A. Chronically increased intra-abdominal pressure produces systemic hypertension in dogs. Int. J. Obes. Relat. Metab. Disord. 2000, 24, 819-824. [CrossRef]

16. Dwyer, T.M.; Banks, S.A.; Alonso-Galicia, M.; Cockrell, K.; Carroll, J.F.; Bigler, S.A.; Hall, J.E. Distribution of renal medullary hyaluronan in lean and obese rabbits. Kidney Int. 2000, 58, 721-729. [CrossRef]

17. Hall, J.E.; Henegar, J.R.; Dwyer, T.M.; Liu, J.; da Silva, A.A.; Kuo, J.J.; Tallam, L. Is obesity a major cause of chronic kidney disease? Adv. Ren. Replace. Ther. 2004, 11, 41-54. [CrossRef]

18. Fox, C.S.; Larson, M.G.; Leip, E.P.; Culleton, B.; Wilson, P.W.; Levy, D. Predictors of new-onset kidney disease in a communitybased population. J. Amer. Med. Assoc. 2004, 291, 844-850. [CrossRef] 
19. Iseki, K.; Ikemiya, Y.; Kinjo, K.; Inoue, T.; Iseki, C.; Takishita, S. Body mass index and the risk of development of end-stage renal disease in a screened cohort. Kidney Int. 2004, 65, 1870-1876. [CrossRef]

20. Hsu, C.Y.; McCulloch, C.E.; Iribarren, C.; Darbinian, J.; Go, A.S. Body mass index and risk for end-stage renal disease. Ann. Intern. Med. 2006, 144, 21-28. [CrossRef]

21. Tanner, R.M.; Brown, T.M.; Muntner, P. Epidemiology of Obesity, the Metabolic Syndrome, and Chronic Kidney Disease. Curr. Hypertens. Rep. 2012, 14, 152-159. [CrossRef] [PubMed]

22. Kramer, H.J.; Saranathan, A.; Luke, A.; Durazo-Arvizu, R.A.; Guichan, C.; Hou, S.; Cooper, R. Increasing body mass index and obesity in the incident ESRD population. J. Am. Soc. Nephrol. 2006, 17, 1453-1459. [CrossRef] [PubMed]

23. Wang, Z.; Zhang, J.; Chan, S.; Cameron, A.; Healy, H.G.; Venuthurupalli, S.K.; Tan, K.-S.; Hoy, W.E. BMI and its association with death and the initiation of renal replacement therapy (RRT) in a cohort of patients with chronic kidney disease (CKD). BMC Nephrol. 2019, 20, 329. [CrossRef] [PubMed]

24. Bergmann, C.; Guay-Woodford, L.M.; Harris, P.C.; Horie, S.; Peters, D.J.M.; Torres, V.E. Polycystic kidney disease. Nat. Rev. Dis. Primers. 2018, 4, 50. [CrossRef]

25. Cornec-Le Gall, E.; Alam, A.; Perrone, R.D. Autosomal dominant polycystic kidney disease. Lancet 2019, 393, 919-935. [CrossRef]

26. Schrier, R.W.; Abebe, K.Z.; Perrone, R.D.; Torres, V.E.; Braun, W.E.; Steinman, T.I.; Winklhofer, F.T.; Brosnahan, G.; Czarnecki, P.G.; Hogan, M.C.; et al. Blood Pressure in Early Autosomal Dominant Polycystic Kidney Disease. N. Engl. J. Med. 2014, 371, 2255-2266. [CrossRef]

27. Nowak, K.L.; Steele, C.; Gitomer, B.; Wang, W.; Ouyang, J.; Chonchol, M.B. Overweight and Obesity and Progression of ADPKD. Clin. J. Am. Soc. Nephrol. 2021, 16, 908-915. [CrossRef]

28. Wang, Y.; Chen, X.; Song, Y.; Caballero, B.; Cheskin, L.J. Association between obesity and kidney disease: A systematic review and meta-analysis. Kidney Int. 2008, 73, 19-33. [CrossRef]

29. Pinto-Sietsma, S.-J.; Navis, G.; Janssen, W.M.T.; de Zeeuw, D.; Gans, R.O.B.; de Jong, P.E. A central body fat distribution is related to renal function impairment, even in lean subjects. Am. J. Kidney Dis. 2003, 41, 733-741. [CrossRef]

30. Chang, A.; Van Horn, L.; Jacobs, D.R., Jr.; Liu, K.; Muntner, P.; Newsome, B.; Shoham, D.A.; Durazo-Arvizu, R.; BibbinsDomingo, K.; Reis, J.; et al. Lifestyle-related factors, obesity, and incident microalbuminuria: The CARDIA (Coronary Artery Risk Development in Young Adults) study. Am. J. Kidney Dis. 2013, 62, 267-275. [CrossRef]

31. Thoenes, M.; Reil, J.C.; Khan, B.V.; Bramlage, P.; Volpe, M.; Kirch, W.; Böhm, M. Abdominal obesity is associated with microalbuminuria and an elevated cardiovascular risk profile in patients with hypertension. Vasc. Health Risk Manag. 2009, 5, 577-585. [CrossRef] [PubMed]

32. Foster, M.C.; Hwang, S.J.; Massaro, J.M.; Hoffmann, U.; DeBoer, I.H.; Robins, S.J.; Vasan, R.S.; Fox, C.S. Association of subcutaneous and visceral adiposity with albuminuria: The Framingham Heart Study. Obesity 2011, 19, 1284-1289. [CrossRef] [PubMed]

33. Gelber, R.P.; Kurth, T.; Kausz, A.T.; Manson, J.E.; Buring, J.E.; Levey, A.S.; Gaziano, J.M. Association between body mass index and CKD in apparently healthy men. Am. J. Kidney Dis. 2005, 46, 871-880. [CrossRef]

34. Kramer, H.; Luke, A.; Bidani, A.; Cao, G.; Cooper, R.; McGee, D. Obesity and prevalent and incident CKD: The Hypertension Detection and Follow-Up Program. Am. J. Kidney Dis. 2005, 46, 587-594. [CrossRef]

35. de Boer, I.H.; Katz, R.; Fried, L.F.; Ix, J.H.; Luchsinger, J.; Sarnak, M.J.; Shlipak, M.G.; Siscovick, D.S.; Kestenbaum, B. Obesity and change in estimated GFR among older adults. Am. J. Kidney Dis. 2009, 54, 1043-1051. [CrossRef]

36. Lu, J.L.; Molnar, M.Z.; Naseer, A.; Mikkelsen, M.K.; Kalantar-Zadeh, K.; Kovesdy, C.P. Association of age and BMI with kidney function and mortality: A cohort study. Lancet Diabetes Endocrinol. 2015, 3, 704-714. [CrossRef]

37. Vivante, A.; Golan, E.; Tzur, D.; Leiba, A.; Tirosh, A.; Skorecki, K.; Calderon-Margalit, R. Body mass index in 1.2 million adolescents and risk for end-stage renal disease. Arch. Intern. Med. 2012, 172, 1644-1650. [CrossRef]

38. Bray, G.A. Overweight is risking fate. Definition, classification, prevalence, and risks. Ann. N. Y. Acad. Sci. 1987, 499, 14-28. [CrossRef]

39. Chang, T.-J.; Zheng, C.-M.; Wu, M.-Y.; Chen, T.-T.; Wu, Y.-C.; Wu, Y.-L.; Lin, H.-T.; Zheng, J.-Q.; Chu, N.-F.; Lin, Y.-M.; et al. Relationship between body mass index and renal function deterioration among the Taiwanese chronic kidney disease population. Sci. Rep. 2018, 8, 6908. [CrossRef]

40. Herrington, W.G.; Smith, M.; Bankhead, C.; Matsushita, K.; Stevens, S.; Holt, T.; Hobbs, F.D.R.; Coresh, J.; Woodward, M. Body-mass index and risk of advanced chronic kidney disease: Prospective analyses from a primary care cohort of 1.4 million adults in England. PLoS ONE 2017, 12, e0173515. [CrossRef]

41. Iseki, K. Body mass index and the risk of chronic renal failure: The Asian experience. Contrib. Nephrol. 2006, 151, 42-56. [CrossRef] [PubMed]

42. Shankar, A.; Leng, C.; Chia, K.S.; Koh, D.; Tai, E.S.; Saw, S.M.; Lim, S.C.; Wong, T.Y. Association between body mass index and chronic kidney disease in men and women: Population-based study of Malay adults in Singapore. Nephrol. Dial. Transplant. 2008, 23, 1910-1918. [CrossRef]

43. Horber, F.F.; Gruber, B.; Thomi, F.; Jensen, E.X.; Jaeger, P. Effect of sex and age on bone mass, body composition and fuel metabolism in humans. Nutrition 1997, 13, 524-534. [CrossRef]

44. Kuk, J.L.; Lee, S.; Heymsfield, S.B.; Ross, R. Waist circumference and abdominal adipose tissue distribution: Influence of age and sex. Am. J. Clin. Nutr. 2005, 81, 1330-1334. [CrossRef] 
45. Othman, M.; Kawar, B.; El Nahas, A.M. Influence of obesity on progression of non-diabetic chronic kidney disease: A retrospective cohort study. Nephron. Clin. Pract. 2009, 113, c16-c23. [CrossRef] [PubMed]

46. MacLaughlin, H.L.; Pike, M.; Selby, N.M.; Siew, E.; Chinchilli, V.M.; Guide, A.; Stewart, T.G.; Himmelfarb, J.; Go, A.S.; Parikh, C.R.; et al. Body mass index and chronic kidney disease outcomes after acute kidney injury: A prospective matched cohort study. BMC Nephrol. 2021, 22, 200. [CrossRef]

47. Khedr, A.; Khedr, E.; House, A.A. Body mass index and the risk of progression of chronic kidney disease. J. Ren. Nutr. 2011, 21, 455-461. [CrossRef]

48. Mohsen, A.; Brown, R.; Hoefield, R.; Kalra, P.A.; O'Donoghue, D.; Middleton, R.; New, D. Body mass index has no effect on rate of progression of chronic kidney disease in subjects with type 2 diabetes mellitus. J. Nephrol. 2012, 25, 384-393. [CrossRef]

49. Brown, R.N.K.L.; Mohsen, A.; Green, D.; Hoefield, R.A.; Summers, L.K.M.; Middleton, R.J.; O'Donoghue, D.J.; Kalra, P.A.; New, D.I. Body mass index has no effect on rate of progression of chronic kidney disease in non-diabetic subjects. Nephrol. Dial. Transplant. 2012, 27, 2776-2780. [CrossRef]

50. Lowrie, E.G.; Lew, N.L. Death risk in hemodialysis patients: The predictive value of commonly measured variables and an evaluation of death rate differences between facilities. Am. J. Kidney Dis. 1990, 15, 458-482. [CrossRef]

51. Kalantar-Zadeh, K.; Block, G.; Humphreys, M.H.; Kopple, J.D. Reverse epidemiology of cardiovascular risk factors in maintenance dialysis patients. Kidney Int. 2003, 63, 793-808. [CrossRef] [PubMed]

52. Kalantar-Zadeh, K.; Block, G.; Horwich, T.; Fonarow, G.C. Reverse epidemiology of conventional cardiovascular risk factors in patients with chronic heart failure. J. Am. Coll. Cardiol. 2004, 43, 1439-1444. [CrossRef] [PubMed]

53. Leavey, S.F.; McCullough, K.; Hecking, E.; Goodkin, D.; Port, F.K.; Young, E.W. Body mass index and mortality in 'healthier' as compared with 'sicker' haemodialysis patients: Results from the Dialysis Outcomes and Practice Patterns Study (DOPPS). Nephrol. Dial. Transplant. 2001, 16, 2386-2394. [CrossRef]

54. Molnar, M.Z.; Streja, E.; Kovesdy, C.P.; Bunnapradist, S.; Sampaio, M.S.; Jing, J.; Krishnan, M.; Nissenson, A.R.; Danovitch, G.M.; Kalantar-Zadeh, K. Associations of body mass index and weight loss with mortality in transplant-waitlisted maintenance hemodialysis patients. Am. J. Transplant. 2011, 11, 725-736. [CrossRef] [PubMed]

55. Horwich, T.B.; Fonarow, G.C.; Hamilton, M.A.; MacLellan, W.R.; Woo, M.A.; Tillisch, J.H. The relationship between obesity and mortality in patients with heart failure. J. Am. Coll. Cardiol. 2001, 38, 789-795. [CrossRef]

56. Fung, F.; Sherrard, D.J.; Gillen, D.L.; Wong, C.; Kestenbaum, B.; Seliger, S.; Ball, A.; Stehman-Breen, C. Increased risk for cardiovascular mortality among malnourished end-stage renal disease patients. Am. J. Kidney Dis. 2002, 40, 307-314. [CrossRef]

57. Lee, M.J.; Park, J.T.; Park, K.S.; Kwon, Y.E.; Han, S.H.; Kang, S.-W.; Choi, K.H.; Oh, K.-H.; Park, S.K.; Chae, D.W.; et al. Normal body mass index with central obesity has increased risk of coronary artery calcification in Korean patients with chronic kidney disease. Kidney Int. 2016, 90, 1368-1376. [CrossRef]

58. Grantham, J.J.; Torres, V.E.; Chapman, A.B.; Guay-Woodford, L.M.; Bae, K.T.; King, B.F.; Wetzel, L.H.; Baumgarten, D.A.; Kenney, P.J.; Harris, P.C.; et al. Volume Progression in Polycystic Kidney Disease. N. Engl. J. Med. 2006, 354, 2122-2130. [CrossRef]

59. Irazabal, M.V.; Rangel, L.J.; Bergstralh, E.J.; Osborn, S.L.; Harmon, A.J.; Sundsbak, J.L.; Bae, K.T.; Chapman, A.B.; Grantham, J.J.; Mrug, M.; et al. Imaging Classification of Autosomal Dominant Polycystic Kidney Disease: A Simple Model for Selecting Patients for Clinical Trials. J. Am. Soc. Nephrol. 2015, 26, 160-172. [CrossRef]

60. Torres, V.E.; Chapman, A.B.; Perrone, R.D.; Bae, K.T.; Abebe, K.Z.; Bost, J.E.; Miskulin, D.C.; Steinman, T.I.; Braun, W.E.; Winklhofer, F.T.; et al. Analysis of baseline parameters in the HALT polycystic kidney disease trials. Kidney Int. 2012, 81, 577-585. [CrossRef]

61. Nowak, K.L.; You, Z.; Gitomer, B.; Brosnahan, G.; Torres, V.E.; Chapman, A.B.; Perrone, R.D.; Steinman, T.I.; Abebe, K.Z.; Rahbari-Oskoui, F.F.; et al. Overweight and Obesity Are Predictors of Progression in Early Autosomal Dominant Polycystic Kidney Disease. J. Am. Soc. Nephrol. 2018, 29, 571-578. [CrossRef] [PubMed]

62. Freise, J.; Tavakol, M.; Gao, Y.; Klein, O.; Lee, B.K.; Freise, C.; Park, M. The Effect of Enlarged Kidneys on Calculated Body Mass Index Categorization in Transplant Recipients With ADPKD. Kidney Int. Rep. 2019, 4, 606-609. [CrossRef]

63. Barberio, A.M.; Alareeki, A.; Viner, B.; Pader, J.; Vena, J.E.; Arora, P.; Friedenreich, C.M.; Brenner, D.R. Central body fatness is a stronger predictor of cancer risk than overall body size. Nat. Commun. 2019, 10, 383. [CrossRef] [PubMed]

64. Pi-Sunyer, F.X. The epidemiology of central fat distribution in relation to disease. Nutr. Rev. 2004, 62, S120-S126. [CrossRef] [PubMed]

65. Choe, S.S.; Huh, J.Y.; Hwang, I.J.; Kim, J.I.; Kim, J.B. Adipose Tissue Remodeling: Its Role in Energy Metabolism and Metabolic Disorders. Front. Endocrinol. 2016, 7, 30. [CrossRef] [PubMed]

66. Chait, A.; den Hartigh, L.J. Adipose Tissue Distribution, Inflammation and Its Metabolic Consequences, Including Diabetes and Cardiovascular Disease. Front. Cardiovasc. Med. 2020, 7, 22. [CrossRef] [PubMed]

67. Nowak, K.L.; Hopp, K. Metabolic Reprogramming in Autosomal Dominant Polycystic Kidney Disease: Evidence and Therapeutic Potential. Clin. J. Am. Soc. Nephrol. 2020, 15, 577-584. [CrossRef] [PubMed]

68. Shuster, A.; Patlas, M.; Pinthus, J.H.; Mourtzakis, M. The clinical importance of visceral adiposity: A critical review of methods for visceral adipose tissue analysis. Br. J. Radiol. 2012, 85, 1-10. [CrossRef]

69. Burhans, M.S.; Hagman, D.K.; Kuzma, J.N.; Schmidt, K.A.; Kratz, M. Contribution of Adipose Tissue Inflammation to the Development of Type 2 Diabetes Mellitus. Compr. Physiol. 2018, 9, 1-58. [CrossRef] 
70. Young, J.A.; Hwang, S.-J.; Sarnak, M.J.; Hoffmann, U.; Massaro, J.M.; Levy, D.; Benjamin, E.J.; Larson, M.G.; Vasan, R.S.; O'Donnell, C.J.; et al. Association of visceral and subcutaneous adiposity with kidney function. Clin. J. Am. Soc. Nephrol. CJASN 2008, 3, 1786-1791. [CrossRef]

71. Reddy, P.; Lent-Schochet, D.; Ramakrishnan, N.; McLaughlin, M.; Jialal, I. Metabolic syndrome is an inflammatory disorder: A conspiracy between adipose tissue and phagocytes. Clin. Chim. Acta 2019, 496, 35-44. [CrossRef] [PubMed]

72. Kahn, C.R.; Wang, G.; Lee, K.Y. Altered adipose tissue and adipocyte function in the pathogenesis of metabolic syndrome. J. Clin. Investig. 2019, 129, 3990-4000. [CrossRef] [PubMed]

73. Zhang, Y.; Hao, J.; Tarrago, M.G.; Warner, G.M.; Giorgadze, N.; Wei, Q.; Huang, Y.; He, K.; Chen, C.; Peclat, T.R.; et al. FBF1 deficiency promotes beiging and healthy expansion of white adipose tissue. Cell Rep. 2021, 36, 109481. [CrossRef] [PubMed]

74. Reyes-Farias, M.; Fos-Domenech, J.; Serra, D.; Herrero, L.; Sánchez-Infantes, D. White adipose tissue dysfunction in obesity and aging. Biochem. Pharmacol. 2021, 192, 114723. [CrossRef]

75. Okhunov, Z.; Mues, A.C.; Kline, M.; Haramis, G.; Xu, B.; Mirabile, G.; Vira, M.; Landman, J. Evaluation of perirenal fat as a predictor of cT 1a renal cortical neoplasm histopathology and surgical outcomes. J. Endourol. 2012, 26, 911-916. [CrossRef]

76. Foster, M.C.; Hwang, S.J.; Porter, S.A.; Massaro, J.M.; Hoffmann, U.; Fox, C.S. Fatty kidney, hypertension, and chronic kidney disease: The Framingham Heart Study. Hypertens 2011, 58, 784-790. [CrossRef]

77. Wei, G.; Sun, H.; Dong, K.; Hu, L.; Wang, Q.; Zhuang, Q.; Zhu, Y.; Zhang, X.; Shao, Y.; Tang, H.; et al. The thermogenic activity of adjacent adipocytes fuels the progression of ccRCC and compromises anti-tumor therapeutic efficacy. Cell Metab. 2021, 33, 2021-2039.e8. [CrossRef]

78. Ahima, R.S.; Lazar, M.A. Adipokines and the peripheral and neural control of energy balance. Mol. Endocrinol. 2008, 22, $1023-1031$. [CrossRef]

79. Considine, R.V.; Sinha, M.K.; Heiman, M.L.; Kriauciunas, A.; Stephens, T.W.; Nyce, M.R.; Ohannesian, J.P.; Marco, C.C.; McKee, L.J.; Bauer, T.L.; et al. Serum immunoreactive-leptin concentrations in normal-weight and obese humans. N. Engl. J. Med. 1996, 334, 292-295. [CrossRef]

80. de Souza Batista, C.M.; Yang, R.Z.; Lee, M.J.; Glynn, N.M.; Yu, D.Z.; Pray, J.; Ndubuizu, K.; Patil, S.; Schwartz, A.; Kligman, M.; et al. Omentin plasma levels and gene expression are decreased in obesity. Diabetes 2007, 56, 1655-1661. [CrossRef]

81. Samaras, K.; Botelho, N.K.; Chisholm, D.J.; Lord, R.V. Subcutaneous and visceral adipose tissue gene expression of serum adipokines that predict type 2 diabetes. Obesity 2010, 18, 884-889. [CrossRef] [PubMed]

82. Degawa-Yamauchi, M.; Bovenkerk, J.E.; Juliar, B.E.; Watson, W.; Kerr, K.; Jones, R.; Zhu, Q.; Considine, R.V. Serum resistin (FIZZ3) protein is increased in obese humans. J. Clin. Endocrinol. Metab. 2003, 88, 5452-5455. [CrossRef] [PubMed]

83. McTernan, P.G.; McTernan, C.L.; Chetty, R.; Jenner, K.; Fisher, F.M.; Lauer, M.N.; Crocker, J.; Barnett, A.H.; Kumar, S. Increased resistin gene and protein expression in human abdominal adipose tissue. J. Clin. Endocrinol. Metab. 2002, 87, 2407-2410. [CrossRef] [PubMed]

84. Zhang, X.; Yeung, D.C.; Karpisek, M.; Stejskal, D.; Zhou, Z.G.; Liu, F.; Wong, R.L.; Chow, W.S.; Tso, A.W.; Lam, K.S.; et al. Serum FGF21 levels are increased in obesity and are independently associated with the metabolic syndrome in humans. Diabetes. 2008, 57, 1246-1253. [CrossRef]

85. Bastard, J.P.; Jardel, C.; Bruckert, E.; Blondy, P.; Capeau, J.; Laville, M.; Vidal, H.; Hainque, B. Elevated levels of interleukin 6 are reduced in serum and subcutaneous adipose tissue of obese women after weight loss. J. Clin. Endocrinol. Metab. 2000, 85, 3338-3342. [CrossRef]

86. Pickup, J.C.; Chusney, G.D.; Thomas, S.M.; Burt, D. Plasma interleukin-6, tumour necrosis factor alpha and blood cytokine production in type 2 diabetes. Life Sci. 2000, 67, 291-300. [CrossRef]

87. Christiansen, T.; Richelsen, B.; Bruun, J.M. Monocyte chemoattractant protein-1 is produced in isolated adipocytes, associated with adiposity and reduced after weight loss in morbid obese subjects. Int. J. Obes. 2005, 29, 146-150. [CrossRef]

88. Yang, R.Z.; Lee, M.J.; Hu, H.; Pollin, T.I.; Ryan, A.S.; Nicklas, B.J.; Snitker, S.; Horenstein, R.B.; Hull, K.; Goldberg, N.H.; et al. Acute-phase serum amyloid A: An inflammatory adipokine and potential link between obesity and its metabolic complications. PLoS Med. 2006, 3, e287. [CrossRef]

89. Sag, S.; Yildiz, A.; Gullulu, S.; Gungoren, F.; Ozdemir, B.; Cegilli, E.; Oruc, A.; Ersoy, A.; Gullulu, M. Early atherosclerosis in normotensive patients with autosomal dominant polycystic kidney disease: The relation between epicardial adipose tissue thickness and carotid intima-media thickness. Springerplus. 2016, 5, 211. [CrossRef]

90. Hotamisligil, G.S. Inflammation and metabolic disorders. Nature 2006, 444, 860-867. [CrossRef]

91. Lowell, B.B.; Shulman, G.I. Mitochondrial dysfunction and type 2 diabetes. Science 2005, 307, 384-387. [CrossRef] [PubMed]

92. Calabro, P.; Yeh, E.T. Intra-abdominal adiposity, inflammation, and cardiovascular risk: New insight into global cardiometabolic risk. Curr. Hypertens. Rep. 2008, 10, 32-38. [CrossRef] [PubMed]

93. Kim, A.Y.; Lee, Y.S.; Kim, K.H.; Lee, J.H.; Lee, H.K.; Jang, S.-H.; Kim, S.-E.; Lee, G. Y.; Lee, J.-W.; Jung, S.-A.; et al. Adiponectin represses colon cancer cell proliferation via AdipoR1- and -R2-mediated AMPK activation. Mol. Endocrinol. 2010, 24, 1441-1452. [CrossRef] [PubMed]

94. Yamauchi, T.; Kamon, J.; Minokoshi, Y.; Ito, Y.; Waki, H.; Uchida, S.; Yamashita, S.; Noda, M.; Kita, S.; Ueki, K.; et al. Adiponectin stimulates glucose utilization and fatty-acid oxidation by activating AMP-activated protein kinase. Nat. Med. 2002, 8, 1288-1295. [CrossRef] 
95. Zhao, J.; Lawless, M.W. Stop feeding cancer: Pro-inflammatory role of visceral adiposity in liver cancer. Cytokine 2013, 64, 626-637. [CrossRef]

96. Wu, Y.; Zhou, B.P. TNF- $\alpha$ /NF-kB/Snail pathway in cancer cell migration and invasion. Br. J. Cancer 2010, 102, 639-644. [CrossRef]

97. De Meyts, P. The Insulin Receptor and Its Signal Transduction Network. In Endotext; Feingold, K.R., Anawalt, B., Boyce, A., Chrousos, G., de Herder, W.W., Dhatariya, K., Dungan, K., Hershman, J.M., Hofland, J., Kalra, S., et al., Eds.; MDText.com, Inc.: South Dartmouth, MA, USA, 2000.

98. Li, B.; Leung, J.C.K.; Chan, L.Y.Y.; Yiu, W.H.; Tang, S.C.W. A global perspective on the crosstalk between saturated fatty acids and Toll-like receptor 4 in the etiology of inflammation and insulin resistance. Prog. Lipid Res. 2020, 77, 101020. [CrossRef]

99. Menezes, L.F.; Lin, C.C.; Zhou, F.; Germino, G.G. Fatty Acid Oxidation is Impaired in An Orthologous Mouse Model of Autosomal Dominant Polycystic Kidney Disease. EBioMedicine 2016, 5, 183-192. [CrossRef]

100. Kim, K.; Trott, J.F.; Gao, G.; Chapman, A.; Weiss, R.H. Plasma metabolites and lipids associate with kidney function and kidney volume in hypertensive ADPKD patients early in the disease course. BMC Nephrol. 2019, 20, 66. [CrossRef]

101. Klawitter, J.; Klawitter, J.; McFann, K.; Pennington, A.T.; Abebe, K.Z.; Brosnahan, G.; Cadnapaphornchai, M.A.; Chonchol, M.; Gitomer, B.; Christians, U.; et al. Bioactive lipid mediators in polycystic kidney disease. J. Lipid. Res. 2014, 55, 1139-1149. [CrossRef]

102. Ma, C.; Avenell, A.; Bolland, M.; Hudson, J.; Stewart, F.; Robertson, C.; Sharma, P.; Fraser, C.; MacLennan, G. Effects of weight loss interventions for adults who are obese on mortality, cardiovascular disease, and cancer: Systematic review and meta-analysis. Br. Med. J. 2017, 359, j4849. [CrossRef] [PubMed]

103. Franz, M.J.; Boucher, J.L.; Rutten-Ramos, S.; VanWormer, J.J. Lifestyle Weight-Loss Intervention Outcomes in Overweight and Obese Adults with Type 2 Diabetes: A Systematic Review and Meta-Analysis of Randomized Clinical Trials. J. Acad. Nutr. Diet. 2015, 115, 1447-1463. [CrossRef] [PubMed]

104. Kanda, E.; Muneyuki, T.; Suwa, K.; Nakajima, K. Effects of Weight Loss Speed on Kidney Function Differ Depending on Body Mass Index in Nondiabetic Healthy People: A Prospective Cohort. PLoS ONE 2015, 10, e0143434. [CrossRef]

105. Afshinnia, F.; Wilt, T.J.; Duval, S.; Esmaeili, A.; Ibrahim, H.N. Weight loss and proteinuria: Systematic review of clinical trials and comparative cohorts. Nephrol. Dial. Transplant. 2010, 25, 1173-1183. [CrossRef] [PubMed]

106. Morales, E.; Praga, M. The effect of weight loss in obesity and chronic kidney disease. Curr. Hypertens. Rep. 2012, 14, 170-176. [CrossRef]

107. Bolignano, D.; Zoccali, C. Effects of weight loss on renal function in obese CKD patients: A systematic review. Nephrol. Dial. Transplant. 2013, 28 (Suppl. 4), iv82-iv98. [CrossRef]

108. Vasquez, B.; Flock, E.V.; Savage, P.J.; Nagulesparan, M.; Bennion, L.J.; Baird, H.R.; Bennett, P.H. Sustained reduction of proteinuria in type 2 (non-insulin-dependent) diabetes following diet-induced reduction of hyperglycaemia. Diabetologia 1984, 26, 127-133. [CrossRef]

109. Solerte, S.B.; Fioravanti, M.; Schifino, N.; Ferrari, E. Effects of diet-therapy on urinary protein excretion albuminuria and renal haemodynamic function in obese diabetic patients with overt nephropathy. Int. J. Obes. 1989, 13, $203-211$.

110. Saiki, A.; Nagayama, D.; Ohhira, M.; Endoh, K.; Ohtsuka, M.; Koide, N.; Oyama, T.; Miyashita, Y.; Shirai, K. Effect of weight loss using formula diet on renal function in obese patients with diabetic nephropathy. Int. J. Obes. 2005, 29, 1115-1120. [CrossRef]

111. Gilardini, L.; Zulian, A.; Girola, A.; Redaelli, G.; Conti, A.; Invitti, C. Predictors of the early impairment of renal disease in human obesity. Int. J. Obes. 2010, 34, 287-294. [CrossRef]

112. Shen, W.-W.; Chen, H.-M.; Chen, H.; Xu, F.; Li, L.-S.; Liu, Z.-H. Obesity-related glomerulopathy: Body mass index and proteinuria. Clin. J. Am. Soc. Nephrol. 2010, 5, 1401-1409. [CrossRef]

113. Ezequiel, D.G.; Costa, M.B.; Chaoubah, A.; de Paula, R.B. Weight loss improves renal hemodynamics in patients with metabolic syndrome. J. Bras. Nefrol. 2012, 34, 36-42. [CrossRef] [PubMed]

114. Conley, M.M.; McFarlane, C.M.; Johnson, D.W.; Kelly, J.T.; Campbell, K.L.; MacLaughlin, H.L. Interventions for weight loss in people with chronic kidney disease who are overweight or obese. Cochrane Database Syst. Rev. 2021, 2021, CD013119. [CrossRef]

115. Kang, H.M.; Ahn, S.H.; Choi, P.; Ko, Y.-A.; Han, S.H.; Chinga, F.; Park, A.S.D.; Tao, J.; Sharma, K.; Pullman, J.; et al. Defective fatty acid oxidation in renal tubular epithelial cells has a key role in kidney fibrosis development. Nat. Med. 2015, 21, 37-46. [CrossRef] [PubMed]

116. Weimbs, T.; Shillingford, J.M.; Torres, J.; Kruger, S.L.; Bourgeois, B.C. Emerging targeted strategies for the treatment of autosomal dominant polycystic kidney disease. Clin. Kidney. J. 2018, 11, i27-i38. [CrossRef]

117. Moore, S.C.; Patel, A.V.; Matthews, C.E.; de Gonzalez, A.B.; Park, Y.; Katki, H.A.; Linet, M.S.; Weiderpass, E.; Visvanathan, K.; Helzlsouer, K.J.; et al. Leisure time physical activity of moderate to vigorous intensity and mortality: A large pooled cohort analysis. PLoS Med. 2012, 9, e1001335. [CrossRef]

118. Zelle, D.M.; Klaassen, G.; van Adrichem, E.; Bakker, S.J.; Corpeleijn, E.; Navis, G. Physical inactivity: A risk factor and target for intervention in renal care. Nat. Rev. Nephrol. 2017, 13, 152-168. [CrossRef]

119. Beddhu, S.; Baird, B.C.; Zitterkoph, J.; Neilson, J.; Greene, T. Physical activity and mortality in chronic kidney disease (NHANES III). Clin. J. Am. Soc. Nephrol. 2009, 4, 1901-1906. [CrossRef]

120. Martins, P.; Marques, E.A.; Leal, D.V.; Ferreira, A.; Wilund, K.R.; Viana, J.L. Association between physical activity and mortality in end-stage kidney disease: A systematic review of observational studies. BMC Nephrol. 2021, 22, 227. [CrossRef] 
121. American College of Sports Medicine. ACSM Guidelines for Exercise Testing and Prescription, 11th ed.; Lippincott Williams \& Wilkins: Philadelphia, PA, USA, 2020.

122. Chebib, F.T.; Torres, V.E. Autosomal Dominant Polycystic Kidney Disease: Core Curriculum 2016. Am. J. Kidney Dis. 2016, 67, 792-810. [CrossRef]

123. Pickel, L.; Iliuta, I.A.; Scholey, J.; Pei, Y.; Sung, H.K. Dietary Interventions in Autosomal Dominant Polycystic Kidney Disease. Adv. Nutr. 2021. online ahead of print. [CrossRef] [PubMed]

124. Hopp, K.; Catenacci, V.A.; Dwivedi, N.; Kline, T.L.; Wang, W.; You, Z.; Nguyen, D.T.; Bing, K.; Poudyal, B.; Johnson, G.C.; et al. Weight loss and cystic disease progression in autosomal dominant polycystic kidney disease. iScience 2022, 25, 103697. [CrossRef]

125. Testa, F.; Marchiò, M.; Belli, M.; Giovanella, S.; Ligabue, G.; Cappelli, G.; Biagini, G.; Magistroni, R. A pilot study to evaluate tolerability and safety of a modified Atkins diet in ADPKD patients. PharmaNutrition 2019, 9, 100154. [CrossRef]

126. Testa, F.; Marchiò, M.; D’Amico, R.; Giovanella, S.; Ligabue, G.; Fontana, F.; Alfano, G.; Cappelli, G.; Biagini, G.; Magistroni, R. GREASE II. A phase II randomized, 12-month, parallel-group, superiority study to evaluate the efficacy of a Modified Atkins Diet in Autosomal Dominant Polycystic Kidney Disease patients. PharmaNutrition. 2020, 13, 100206. [CrossRef]

127. Warner, G.; Hein, K.Z.; Nin, V.; Edwards, M.; Chini, C.C.; Hopp, K.; Harris, P.C.; Torres, V.E.; Chini, E.N. Food Restriction Ameliorates the Development of Polycystic Kidney Disease. J. Am. Soc. Nephrol. 2016, 27, 1437-1447. [CrossRef] [PubMed]

128. Kipp, K.R.; Rezaei, M.; Lin, L.; Dewey, E.C.; Weimbs, T. A mild reduction of food intake slows disease progression in an orthologous mouse model of polycystic kidney disease. Am. J. Physiol. Renal. Physiol. 2016, 310, F726-F731. [CrossRef]

129. Torres, J.A.; Kruger, S.L.; Broderick, C.; Amarlkhagva, T.; Agrawal, S.; Dodam, J.R.; Mrug, M.; Lyons, L.A.; Weimbs, T. Ketosis Ameliorates Renal Cyst Growth in Polycystic Kidney Disease. Cell Metab. 2019, 30, 1007-1023.e5. [CrossRef]

130. Strubl, S.; Oehm, S.; Torres, J.A.; Grundmann, F.; Haratani, J.; Decker, M.; Vuong, S.; Kaur Bhandal, A.; Methot, N.; Haynie-Cion, R.; et al. Ketogenic dietary interventions in autosomal dominant polycystic kidney disease-A retrospective case series study: First insights into feasibility, safety and effects. Clin. Kidney J. 2021, 1-14, in press. [CrossRef] 